\title{
Preliminary investigations on a polygalacturonase from Aspergillus fumigatus in Chinese Pu'er tea fermentation
}

\author{
Shihui Wang, Zhongshuai Lian ${ }^{\dagger}$, Liuyang Wang, Xiao Yang and Yun Liü ${ }^{*+}$ (D)
}

\begin{abstract}
Background: Polygalacturonase is one kind of pectinases which hydrolyze the alpha-1,4 glycosidic bond between galacturonic acid residue. Polygalacturonase has been widely used in the fields of food, biofuel, and textile industries, in which thermostable polygalacturonase is often demanded at high temperatures of $50-60{ }^{\circ} \mathrm{C}$. Herein, we reported a thermostable polygalacturonase producing from Aspergillus fumigatus isolated from the pile fermentation of Pu'er tea in China.
\end{abstract}

Results: The thermophilic polygalacturonase-producing strain was identified as A. fumigatus L45 on basis of its morphology, physicochemical properties, and 185 rDNA analysis. The crucial fermentation parameters affecting polygalacturonase activity were optimized by response surface methodology (RSM); the optimum fermentation parameters were the following: inoculums concentration of $0.07 \%(\mathrm{v} / \mathrm{v})$, fermentation time of $36 \mathrm{~h}$, $\mathrm{pH}$ of 5.0, and temperature of $45^{\circ} \mathrm{C}$. Under the optimized conditions, the highest polygalacturonase activity of $359.1 \pm 10.1 \mathrm{U} / \mathrm{mL}$ was obtained. The polygalacturonase showed good thermostability and pH stability. The enzyme was activated by metal ions $\mathrm{Zn}^{2+}$ and $\mathrm{Mg}^{2+}$, but inhibited by $\mathrm{K}^{+}$. However, $\mathrm{Na}^{+}$and $\mathrm{Ca}^{2+}$ showed little effects on its activity. $\mathrm{K}_{\mathrm{m}}$ and $V_{\max }$ values were estimated to be $35.0 \mathrm{mg} / \mathrm{mL}$ and $7.69 \mu \mathrm{mol} / \mathrm{mL} / \mathrm{min}$, respectively.

Conclusions: A polygalacturonase from A. fumigatus $L 45$ was preliminarily investigated, the crucial fermentation parameters were optimized by RSM, and the properties of polygalacturonase was examined. The polygalacturonase showed good thermostability and pH stability, which suggested the enzyme has potential applications in the biofuel and textile industries.

Keywords: Polygalacturonase; Aspergillus fumigatus; Identification; Response surface methodology (RSM); Enzymatic properties

\section{Background}

Pectinases, also called pectinolytic enzymes, are a group of enzymes hydrolyzing pectin substrates in plant cell [1]. Pectinases are mainly composed of polygalacturonase (E.C.3.2.1.15), pectin lyase (E.C.4.2.2.10), pectate lyase (E.C.4.2.2.2), and pectinesterase (E.C.3.1.1.11) [2]. The main function of pectinases is to destroy plant tissue and cell wall structure to allow other depolymerases accession to enhance the productivity [3]. Nowadays, pectinases have

\footnotetext{
* Correspondence: liuyun@mail.buct.edu.cn or liuyunprivate@sina.com ${ }^{\dagger}$ Equal contributors

Beijing Key Laboratory of Bioprocess, College of Life Science and Technology, Beijing University of Chemical Technology, Beijing 100029, China
}

been widely used in the fields of food, oils, flavors and pigments extraction, cellulose fibers preparation, coffee and tea fermentations, and oligogalacturonides production [4]. So, it is crucial to screen novel pectinases with remarkable characteristics from native environments $[5,6]$. Pectinases are generally produced from bacteria, fungi, and plants; however, most of the commercial pectinases are from fungal sources [7], which optimal $\mathrm{pH}$ was between 3.0 and 5.5 [8]. Aspergillus species, especially Aspergillus niger, is most commonly used for commercial pectinases production [8-10], followed by Penicillium species [11-13]. Pectinases from bacteria are mainly alkaline with the optimal $\mathrm{pH}$ over 7.0 and mostly used in pulp and paper processing [14-16]. Apart from

\section{苗 Springer}


Bacillus species, little information on pectinases from bacteria has been available to date.

In literature, the optimum temperature of pectinases was mostly within the ranges of $30-50{ }^{\circ} \mathrm{C}$. For instance, pectinases from $A$. niger reported by Kittur et al. showed the maximal activity at $47^{\circ} \mathrm{C}$ [17]. Singh and Appu Rao [18] claimed that two endo-polygalacturonases from A. niger could achieve their maximal activities at 43 and $45{ }^{\circ} \mathrm{C}$. A polygalacturonase from Saccharomyces cerevisiae isolated from marsh grape fruit pulp possessed the maximal activity at $45{ }^{\circ} \mathrm{C}$ [19]. As well known, high temperatures of $50-60{ }^{\circ} \mathrm{C}$ are potentially useful for application in the fabric industry to separate cotton fabrics and polish enzymes, in the paper industry to remedy the retention problems in mechanical pulp bleaching, and in the food industry to clarify juice $[20,21]$. Therefore, thermostable pectinases are highly demanded in these modern industries.

Among the aforementioned four pectinases, polygalacturonase is the most commonly used in food industries. So many researchers have been focusing on the isolation and characterization of thermostable polygalacturonases. For instance, a polygalacturonase from thermophilic fungus Thermoascus aurantiacus had a high thermostability at $60{ }^{\circ} \mathrm{C}$ [1]. The polygalacturonase from Penicillium SPC-F 20 isolated from citrus fruit was found to show the highest activity at $60{ }^{\circ} \mathrm{C}$ [22]. Maller et al. [23] revealed that the polygalacturonase from Aspergillus niveus showed maximum activity at $55{ }^{\circ} \mathrm{C}$ and $\mathrm{pH} 4.0$, and the enzyme was stable at $60{ }^{\circ} \mathrm{C}$ for $90 \mathrm{~min}$. Martins et al. [24] found that the polygalacturonase from $T$. aurantiacus achieved its highest activity at $60-65{ }^{\circ} \mathrm{C}$ and $\mathrm{pH} 4.5-5.5$ and was stable at $50{ }^{\circ} \mathrm{C}$ for $1 \mathrm{~h}$.

In this work, a novel thermostable polygalacturonase produced from the microorganism in the pile fermentation of Pu'er tea in Yunnan province, China, is reported for the first time. The microorganism was then identified on basis of its morphology, physicochemical properties, and $18 \mathrm{~S}$ rDNA analysis. After that, the crucial fermentation parameters affecting polygalacturonase activity were optimized by response surface methodology (RSM). Finally, the enzymatic characterization of the thermostable polygalacturonase was investigated. It is hoped that the findings in this work could facilitate the application of polygalacturonase in biofuel and textile industries.

\section{Methods}

\section{Materials}

Pu'er tea was gifted from Yunnan Pu'er Tea (Group) Co. (Yunnan province, China). The reason of screening the thermophilic strain from Pu'er tea fermentation pile was the fact that the temperature of the pile fermentation of Pu'er tea could always reach more than $60^{\circ} \mathrm{C}$. The strain was isolated, purified, and identified in our lab and kept in $-80{ }^{\circ} \mathrm{C}$ fridge. Pectin from citrus peel (galacturonic acid $\geq 74.0 \%$ (dried basis)) with an item number of P9135 was brought from Sigma-Aldrich (Beijing, China). D-(+)-galacturonic acid was also purchased from SigmaAldrich (Beijing, China). DNeasy plant Mini Kit with a production number of 69104 was bought from Qiagen Co. (Beijing, China). TaKaRa Ex Taq DRR001A, 10× Ex Taq Buffer DRR001A, DL2000 DNA Marker SN125-1, dNTPs, and primers were from Takara Co., Ltd (Dalian, China). All other reagents were of analytical grade and bought from local market in Beijing, China.

Compositions of Luria-Bertani (LB) medium are the following: peptone $1 \mathrm{~g}$, yeast extract $0.5 \mathrm{~g}, \mathrm{NaCl} 1 \mathrm{~g}$, agar $1.5 \mathrm{~g}$, and deionized water $100 \mathrm{~mL}$. Compositions of yeast extract peptone dextrose (YEPD) medium are the following: peptone $2 \mathrm{~g}$, yeast extract $1 \mathrm{~g}$, glucose $2 \mathrm{~g}$, agar $1.5 \mathrm{~g}$, and deionized water $100 \mathrm{~mL}$. Compositions of Congo red medium are the following: pectin $0.1 \mathrm{~g}$, sucrose $2 \mathrm{~g}, \mathrm{MgSO}_{4}$ $0.05 \mathrm{~g}, \mathrm{KCl} 0.05 \mathrm{~g}, \mathrm{Fe}_{2}\left(\mathrm{SO}_{4}\right)_{3} 1 \mathrm{mg}, \mathrm{K}_{2} \mathrm{HPO}_{4} 0.1 \mathrm{~g}, \mathrm{NaNO}_{3}$ $0.3 \mathrm{~g}$, agar $1.5 \mathrm{~g}$, Congo red $0.02 \mathrm{~g}$, and deionized water $100 \mathrm{~mL}$. Compositions of submerge medium are the following: $\mathrm{KCl} 0.05 \mathrm{~g}, \mathrm{MgSO}_{4} 0.1 \mathrm{~g}, \mathrm{NaNO}_{3} 0.1 \mathrm{~g}$, $\mathrm{KH}_{2} \mathrm{PO}_{4} 0.1 \mathrm{~g}, \mathrm{FeSO}_{4} 0.01 \mathrm{~g}$, yeast extract $0.1 \mathrm{~g}$, peptone $0.1 \mathrm{~g}$, sucrose $1.0 \mathrm{~g}$, and deionized water $100 \mathrm{~mL}$. The $\mathrm{pH}$ of the medium was adjusted to 5.0 with $1.0 \mathrm{~N} \mathrm{HCl}$.

\section{Isolation and identification of thermophilic strain Isolation of thermophilic strain}

Sample preparation of $20 \mathrm{~kg}$ of Pu'er tea was fermented for 43 days as optimized previously. The pile of the tea was artificially divided into upper $(1.0-10.0 \mathrm{~cm})$, middle $(10.0-30.0 \mathrm{~cm})$, and lower $(>30.0 \mathrm{~cm})$ layers. The middle layer, with the temperature of $55-65{ }^{\circ} \mathrm{C}$ and $\mathrm{pH}$ of $4.5-6$, was most suitable for the screening of thermophilic strains. So, in this layer, four monitoring points were set for sample collection. Every 3 days, $10 \mathrm{~g}$ of tea samples were obtained from each monitoring point at eight o'clock in the morning. Each tea sample was added with $90 \mathrm{~mL}$ normal saline and homogenized for $3 \mathrm{~min}$. The homogenate was used for primary screening.

Primary screening: The homogenate was divided into two parts. Each part was respectively incubated in LB and YEPD media at $45{ }^{\circ} \mathrm{C}$ for 2 days. After cultivation and crossed purification, the strains were stored in the tube culture at $4{ }^{\circ} \mathrm{C}$. The crossed purification on the solid medium was processed until the strains with the same morphology were examined by microscope. Then the strains were numbered and incubated on Congo red medium using pectin as the solo carbon source. The diameters of the pectin degradation halos $\left(D_{\mathrm{p}}\right)$ and the potency index (defined as the ratio of $D_{\mathrm{p}}$ to the diameters of the colonies $\left.\left.\left(D_{\mathrm{c}}\right)\right), D_{\mathrm{p}} / D_{\mathrm{c}}\right)$ were calculated and used as the standard to screen the pectinase-producing strain. 
Secondary screening: After primary screening test, seven microbes with higher potency indexes and $D_{\mathrm{p}}$ values were further tested by submerged fermentation at $45{ }^{\circ} \mathrm{C}$. At regular intervals $(12,24$, and $36 \mathrm{~h})$, aliquots of fermentation broth were withdrawn and centrifuged at 12,000 rpm and $4{ }^{\circ} \mathrm{C}$. The supernatant was served as the crude pectinase. The pectinase activity was assayed from the aspect of polygalacturonase activity, i.e., the enzyme activity was determined by measuring the release of reducing groups using the method of 3,5-dinitrosalicylic acid (DNS) [25]. $0.2 \mathrm{~mL}$ of crude enzyme solution was mixed with $0.8 \mathrm{~mL}$ of $1 \%(\mathrm{w} / \mathrm{v})$ pectin and incubated at $50{ }^{\circ} \mathrm{C}$ for $10 \mathrm{~min}$ following by adding $1 \mathrm{~mL}$ DNS reagent. The mixture was heated in boiling water bath for $5 \mathrm{~min}$. After cooling, the solution was diluted to $10 \mathrm{~mL}$ and centrifuged at $6000 \mathrm{rpm}$ for $10 \mathrm{~min}$. The supernatant was collected to determine enzyme activity by measuring absorbance at $540 \mathrm{~nm}$. One "polygalacturonase unit" was defined as the amount of the enzyme in $1 \mathrm{~mL}$ fermentation broth that hydrolyzed $1 \mu \mathrm{g}$ reducing sugar (herein, it is galacturonic acid) per minute under standard assay conditions.

\section{Morphology and culture characters of the strain}

The morphological and cultural characteristics of the strain were observed by naked eyes after incubated on LB, YEPD, and Congo red media for $24 \mathrm{~h}$. The spores of the strain were examined by SU1510 Hitachi scanning electron microscope (SEM) (Hitachi City, Japan). Before observation, the strain cell was first fixed by glutaraldehyde (2.5\%, pH 7.4) and osmic acid solution (1\%) and then dehydrated by ethanol followed by being dried in a vacuum freeze dryer for $12 \mathrm{~h}$. The specimen was sputter-coated with gold in an ion coater for $2 \mathrm{~min}$.

\section{Physicochemical properties of the strain}

A total of 15 tests were conducted for physiological characterization experiments, including 9 types of carbon sources and 6 types of nitrogen sources utilization in submerged fermentation medium. The tested carbon sources were sucrose, pectin, fructose, glucose, maltose, lactose, galactose, and soluble starch. The tested nitrogen sources were beef extract, peptone, $\mathrm{NaNO}_{3},\left(\mathrm{NH}_{4}\right)_{2} \mathrm{SO}_{4}$, urea, and yeast extract. The culture stability of the strain growth on submerged fermentation medium was also examined at $45{ }^{\circ} \mathrm{C}$ for $48 \mathrm{~h}$.

\section{5 rDNA identification and phylogenetic analysis of the strain}

The methods of 3,5-dinitrosalicylic acid (DNA) isolation, $18 \mathrm{~S}$ rDNA amplification, and phylogenetic analysis of the strain were in accordance with the methods described by Lin and Liu [26]. The nucleotide sequence coding for the $18 \mathrm{~S}$ rDNA gene of strain (607 bp) was deposited in the GenBank database with accession number of KJ818296.
Phylogenetic and molecular evolutionary analyses were conducted using MEGA version 5.0 software.

\section{Optimization of fermentation parameters using RSM}

The single factor experiments revealed that inoculums concentration (0.04-0.08\%), pH (4.5-5.5), and temperature $\left(40-50{ }^{\circ} \mathrm{C}\right)$ were three crucial variables affecting the production of polygalacturonase from Aspergillus fumigatus (data not shown). Therefore, the three aforementioned parameters were optimized using RSM. A three-levelthree-factor center composite rotation design (CCRD) with three star points and 17 trials (also known as the Box-Behnken (BB) design) was employed to fit a second-order response surface $[27,28]$. To reduce the error, experimental designs were carried out at random. A second-order polynomial equation was obtained from the BB design and shown in Eq. 1:

$$
Y=\beta_{0}+\sum \beta_{i} X_{i}+\sum \beta_{i i} X_{i}^{2}+\sum \sum \beta_{i j} X_{i} X_{j}
$$

where $Y$ represented polygalacturonase activity (dependent variable); $\beta_{O}$ was the constant coefficient; $\beta_{i}, \beta_{i i}$, and $\beta_{i j}$ were the coefficients for the linear, quadratic, and interaction terms, respectively; and $X_{i}$ and $X_{j}$ represented the independent variables. Subscript $i$ and $j$ were the numbers 1 to 3 .

Coefficient of determination $\left(R^{2}\right)$ and analysis of variance (ANOVA) were used to evaluate the fit of the second-order polynomial equation (Eq. 1). The contour plots and threedimensional response surfaces were attained by holding one of the independent variances constant while changing the level of other variables.

\section{Enzymatic characterization of the polygalacturonase The purification of polygalacturonase}

The polygalacturonase-producing strain A. fumigatus was incubated in submerged medium for $36 \mathrm{~h}$. The fermentation broth was centrifuged at 12,000 rpm and $4{ }^{\circ} \mathrm{C}$ for $10 \mathrm{~min}$. The supernatant was filtered with a polyethersulfone membrane $(0.22 \mu \mathrm{m})$ followed by being dialyzed with a dialysis bag (molecular weight cut off, $1 \mathrm{kDa}$ ) at $4{ }^{\circ} \mathrm{C}$ for $24 \mathrm{~h}$. Then the solution was transferred into another dialysis bag with a molecular weight cut off of $25 \mathrm{kDa}$ to be concentrated by $10 \%$ $(\mathrm{m} / \mathrm{v})$ polyethylene glycol (PEG) at $4{ }^{\circ} \mathrm{C}$ for $24 \mathrm{~h}$. Mixture solutions of trichloroacetic acid/acetone (v/v, 1:4) were put into the concentrated enzyme solution to precipitate the enzyme at $-20{ }^{\circ} \mathrm{C}$ for $12 \mathrm{~h}$. The volume ratio of enzyme solution to mixture organic solvents was 1:4. After precipitation, the enzyme solution was centrifuged at 12,000 rpm for $10 \mathrm{~min}$. The protein pellet was obtained and washed by $100 \%$ acetone for three times and dried as the crude enzyme for the following experimental use. The enzyme protein content was monitored 
by Bradford protein assay method using Bradford reagent from BioRad at a wavelength of $595 \mathrm{~nm}$ with a standard calibration curve of BSA. The purity and molecular weight of polygalacturonase were measured by SDS-PAGE [8].

\section{Effects of $\mathrm{pH}$, temperature, and metal ions on polygalacturonase activity}

The effects of $\mathrm{pH}(\mathrm{pH}=2.0$ to 8.0$)$, temperature (20 to $\left.80{ }^{\circ} \mathrm{C}\right)$, and metal ions $\left(\mathrm{K}^{+}, \mathrm{Na}^{+}, \mathrm{Ca}^{2+}, \mathrm{Zn}^{2+}\right.$, and $\left.\mathrm{Mg}^{2+}\right)$ on polygalacturonase activity were investigated. The polygalacturonase activity was assayed according to the method depicted in "Isolation of thermophilic strain" section. The relative polygalacturonase activity was estimated by Eq. 2:

$$
\begin{aligned}
& \text { Relative enzyme activity (\%) } \\
& =\frac{\text { Enzyme activity after treatment }}{\text { Enzyme activity before treatment }}
\end{aligned}
$$

Besides, the pH stability and thermostability of polygalacturonase were also evaluated. For $\mathrm{pH}$ stability, the enzyme was incubated at a certain $\mathrm{pH}(\mathrm{pH} 2-8)$ for $24 \mathrm{~h}$ before activity measurement. In view of thermostability, the enzyme was incubated at a certain temperature $\left(20-80{ }^{\circ} \mathrm{C}\right)$ for $2 \mathrm{~h}$ before activity measurement.

\section{Determination of $K_{m}$ and $V_{\max }$ values of enzyme kinetics}

The kinetics parameters of polygalacturonase were fitted to the Michaelis-Menten Eq. 3:

$$
v=\frac{V_{\max } \times[S]}{K_{\mathrm{m}}+[S]}
$$

where $v$ is the reaction velocity (dependent variable), $V_{\max }$ is the maximum velocity, $K_{\mathrm{m}}$ is the MichaelisMenten constant, and $[S]$ is the concentration of substrate (independent variable). To obtain the values of $K_{\mathrm{m}}$ and $V_{\text {max }}$, Eq. 3 was usually converted into Lineweaver-Burk equation by taking the reciprocal:

$$
\frac{1}{v}=\frac{K_{\mathrm{m}}+[S]}{V_{\max } \times[S]}=\frac{K_{\mathrm{m}}}{V_{\max }} \frac{1}{[S]}+\frac{1}{V_{\max }}
$$

Therefore, the values of $K_{\mathrm{m}}$ and $V_{\max }$ can be obtained from the intercept and slope of the $1 / v$ vs. $1 /[S]$ plot [29]. Herein, the substrate (pectin) concentrations used were in the range of 0.2 to $1.8 \%(\mathrm{w} / \mathrm{v})$. Experiments were conducted at $\mathrm{pH} 5$ and $45^{\circ} \mathrm{C}$.
Table 1 Primary selection of polygalacturonase-producing isolates on Congo red medium

\begin{tabular}{ll}
\hline Potency index $\left(D_{\mathrm{p}} / D_{c}\right)$ & Number of isolates \\
\hline$D_{\mathrm{p}} / D_{c}>3.5$ & 7 \\
$3.5>D_{\mathrm{p}} / D_{c}>2.0$ & 58 \\
$2.0>D_{\mathrm{p}} / D_{c}$ & 78 \\
$D_{\mathrm{p}} / D_{c}=0$ & 57 \\
\hline
\end{tabular}

\section{Results and discussion}

Isolation and identification of thermophilic strains Isolation of thermophilic polygalacturonase-producing strains

To deeply survey the thermophilic polygalacturonaseproducing strains, 84 bacteria and 116 fungi were separated from the pile fermentation of Pu'er tea. The total 200 isolates were subjected to primary selection via Congo red medium using pectin as the sole source of carbon. The results showed that 57 isolates $(28.5 \%)$ could not grow on the Congo red medium, while 143 isolates $(71.5 \%)$ showed different diameters of pectin degradation halos, indicating that they have extracellular pectinolytic activities. Among the 143 pectinolytic isolates, the potency indexes $\left(D_{\mathrm{p}} / D_{\mathrm{c}}\right)$ were estimated to screen the strains producing extracellular pectinolytic activity [4]. As shown in Table 1, 7 isolates had a potency index above 3.5 , which were categorized as high pectinase-producing strains. Fifty-eight isolates presenting the potency index between 2.0 and 3.5 were classified into moderate pectinase-producing strains. While other 78 isolates with the potency index less than 2.0 were relative to low pectinase-producing microbes. Seven high pectinase-producing strains were further screened

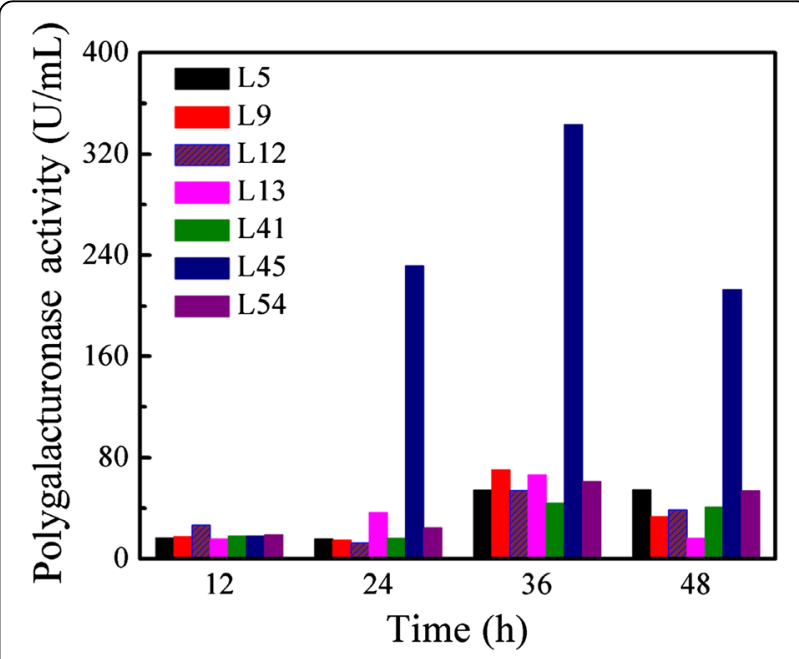

Fig. 1 Secondary selection of the seven high polygalacturonaseproducing isolates using submerged fermentation. The serial numbers of the isolates in the total 200 isolates were given in the figure 
through submerged fermentation by quantitative estimation of pectinase activities.

In the submerged fermentation, the strains were screened in the aspect of polygalacturonase activity using the DNS method (Fig. 1). It was demonstrated that strain L45 presented the highest polygalacturonase activity of $343 \mathrm{U} / \mathrm{mL}$ after $36 \mathrm{~h}$ of fermentation. Furthermore, the propagating stability of strain L45 was evaluated, and the results showed that the polygalacturonase activity could maintain ca. $94 \%$ after five generations. It indicated that the strain L45 showed good genetic stability. Hence, it was selected as the potential source of polygalacturonase in the following experiments.

\section{Identification of the strain $L 45$}

The strain L45 was identified according to its characteristics of morphology, physicochemical properties, and $18 \mathrm{~S}$
rDNA. It can be seen from Fig. 2 that the colony of strain L45 was circular regardless of the growth media types, i.e., LB, YEPD, and Congo red media. At the early growth stage, the colony of the strain was white and grew mycelium. SEM analysis results (Fig. 3) showed that the length of the mycelium was about $2.5 \mathrm{~nm}$, and the diameter of the spore was about $15 \mu \mathrm{m}$. In the maturing stage, the colony of the strain displayed smoky green in the center and white around with spores on the surface. Simultaneously, the strain could grow on the medium using sucrose, pectin, fructose, glucose, maltose, lactose, galactose, or soluble starch as the sole carbon source and beef extract, peptone, $\mathrm{NaNO}_{3},\left(\mathrm{NH}_{4}\right)_{2} \mathrm{SO}_{4}$, urea, or yeast extract as the sole nitrogen sources, respectively.

18S rDNA molecular identification, coding for $18 \mathrm{~S}$ ribosomal RNA, is widely used in molecular analysis to
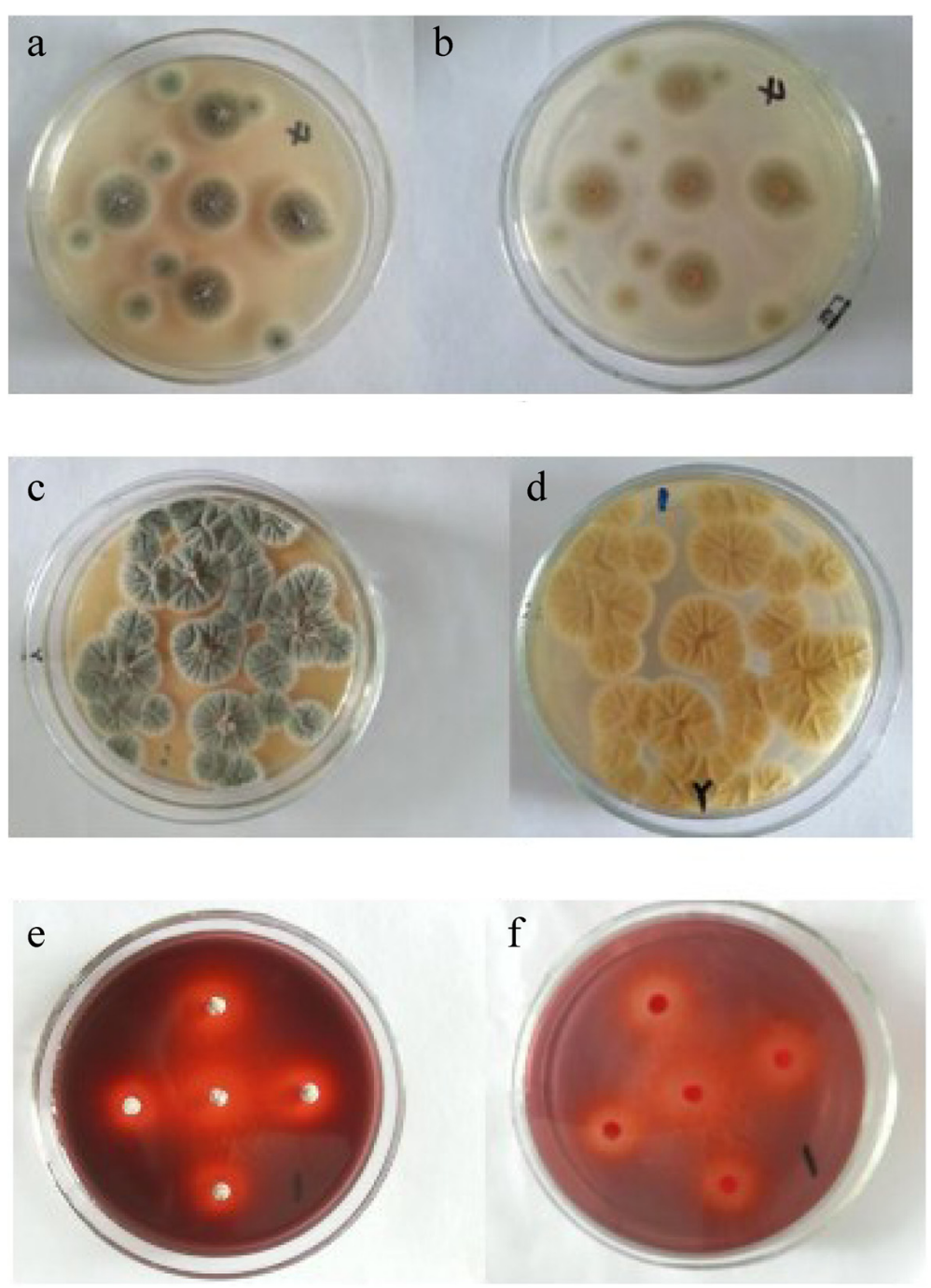

Fig. 2 Morphology of Aspergillus fumigatus L45 cultivated on LB (a and b), YEPD (c and $\mathbf{d}$ ), and Congo red media (e and $\mathbf{f}$ ) 


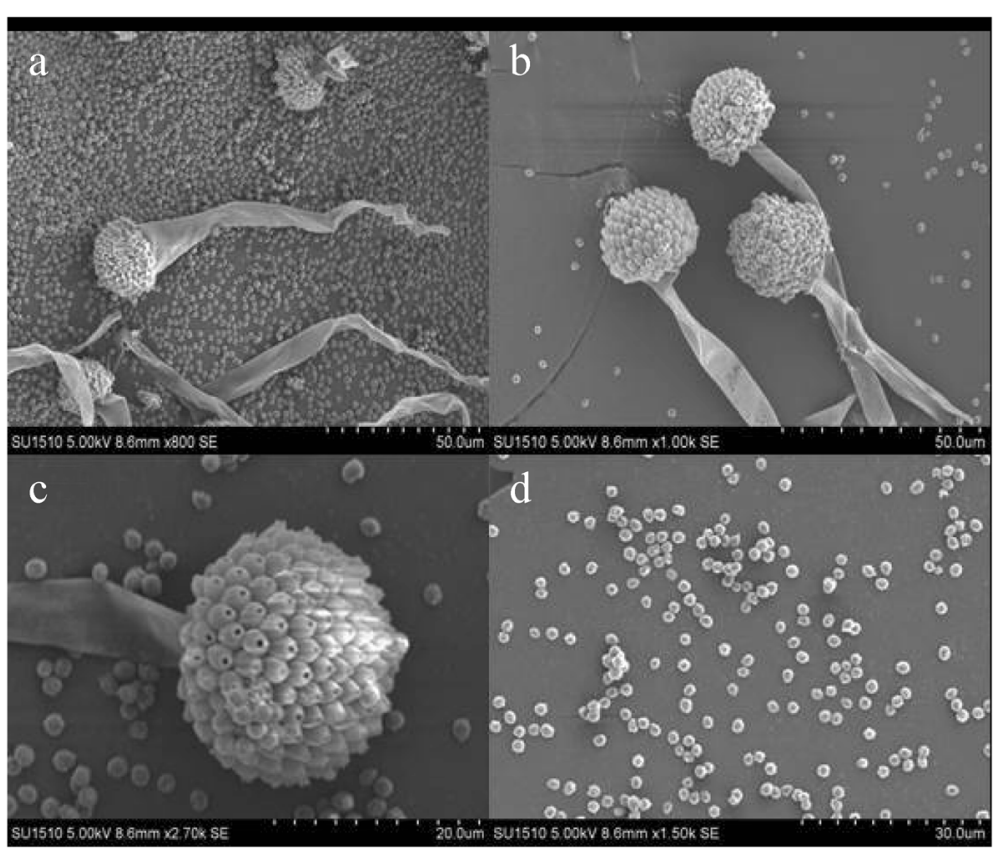

Fig. 3 SEM images of Aspergillus fumigatus L45. $\mathbf{a}, \mathbf{b}$, and $\mathbf{c}$ stand for the SEM images of mature strain; $\mathbf{d}$ stands for the SEM image of immature strain

reconstruct the evolutionary history of organisms due to its slow evolutionary rate [30,31]. Herein, the $18 \mathrm{~S}$ rDNA of the strain L45 was firstly extracted, amplified, and sequenced. Then the $607 \mathrm{bp}$ sequence, as presented in Fig. 4a, was registered in the GenBank database with an accession number of KJ818296. The sequence was compared with previously published sequences of microorganisms in GenBank database using the BLAST program for species identification (http://blast.ncbi.nlm.nih.gov/Blast.cgi). As shown in Fig. 4b, a phylogenetic tree was obtained by applying the neighbor joining method. It can be seen that the L45 strain was $96 \%$ similar to $A$. fumigatus strain NTGMP02. So the strain L45 belongs to A. fumigatus genus. However, the phylogenetic analysis indicates that strain L45 would represent a distinct phyletic line suggesting a new genomic species. Therefore, the strain was identified as A. fumigatus L45.

\section{Fermentation parameters optimization by RSM}

Single factor experiments on effects of fermentation time, carbon source, nitrogen source, metal ions, inoculum concentration, temperature, and $\mathrm{pH}$ on polygalacturonase activity were conducted to determine the main effective factors (data not shown). Results revealed that the main effective factors were inoculum concentration, temperature, and $\mathrm{pH}$ for the polygalacturonase activity produced from the fermentation of A. fumigatus L45. On the basis of these results, the crucial parameters affecting polygalacturonase activity were optimized using RSM through BB design. The optimized experimental designs and results were shown in Table 2.

Through Design Expert 8.0 analysis, a polynomial quadratic equation (Eq. 5) was obtained in terms of coded factors from the experimental data in Table 2:

$$
\begin{aligned}
Y= & 360.12+7.58 \times X_{1}-2.52 \times X_{2}-2.39 \times X_{3} \\
& +1.51 \times X_{1} \times X_{2}-0.94 \times X_{1} \times X_{3}+5.22 \\
& \times X_{2} \times X_{3}-12.78 \times X_{1}{ }^{2}-66.28 \\
& \times X_{2}{ }^{2}-46.48 \times X_{3}{ }^{2}
\end{aligned}
$$

From the ANOVA analysis in Table 3 , the $R^{2}$ was 0.9494 , and the lack of fit tests of model was 0.96 . These values indicated that model equation was highly significant and fitted the response surface regression analysis of the data.

When one variable was set to zero, the contour plots and the three-dimensional response surfaces of the other two variables were graphed in Fig. 5. The figure clearly interpreted the optimal combination of variables and showed the interactions between the two varying factors and their effects on polygalacturonase activity. Therefore, it can be deduced from the figure that the optimal conditions were inoculums concentration $0.07 \%(\mathrm{v} / \mathrm{v})$, temperature $44.91{ }^{\circ} \mathrm{C}$, and $\mathrm{pH} 4.99$. Under the optimized condition, the polygalacturonase activity was predicted to be $361.3 \mathrm{U} / \mathrm{mL}$.

In order to verify the reliability of the derived model (Eq. 5), experiments were carried out in triplicate under optimized conditions. The results showed that the practical polygalacturonase activity of $359.1 \pm 10.1 \mathrm{U} / \mathrm{mL}$ 
a $18 \mathrm{~S}$ rDNA sequences

ACTGGGTGCTACCTGATCCGAGGTCACCTTAGAAAAATAAAGTTGGGTGTC

GGCTGGCGCCGGCCGGGCCTACAGAGCAGGTGACAAAGCCCCATACGCTC

GAGGACCGGACGCGGTGCCGCCGCTGCCTTTCGGGCCCGTCCCCCGGGAG

AGGGGGACGGGGGCCCAACACACAAGCCGTGCTTGAGGGCAGCAATGAC

GCTCGGACAGGCATGCCCCCCGGAATACCAGGGGGCGCAGATTGCGTTCA

AAGACTCGATGATTCACTGAATTCTGCAATTCACATTACTTATCGCATTTCGC

TGCGTTCTTCATCGATGCCGGAACCAAGAGATCCGTTGTTGAAAGTTTTAA

CTGATTACGATAATCAACTCAGACTGCATACTTTCAGAACAGCGTTCATGTT

GGGGTCTTCGGCGGGCGCGGGCCCGGGGGCGCAAGGCCTCCCCGGCGGCC

GTCGAAACGGCGGGCCCGCCGAAGCAACAAGGTACGATAGACACGGGTG

GGAGGTTGGACCCAGAGGGCCCTCACTCGGTAATGATCCTTCCGCAGGTTC

ACCTACGGAAACCTTGTTACGACTTTTACTTCCTCAATGTGGACCAAGAA

b phylogenetic analysis

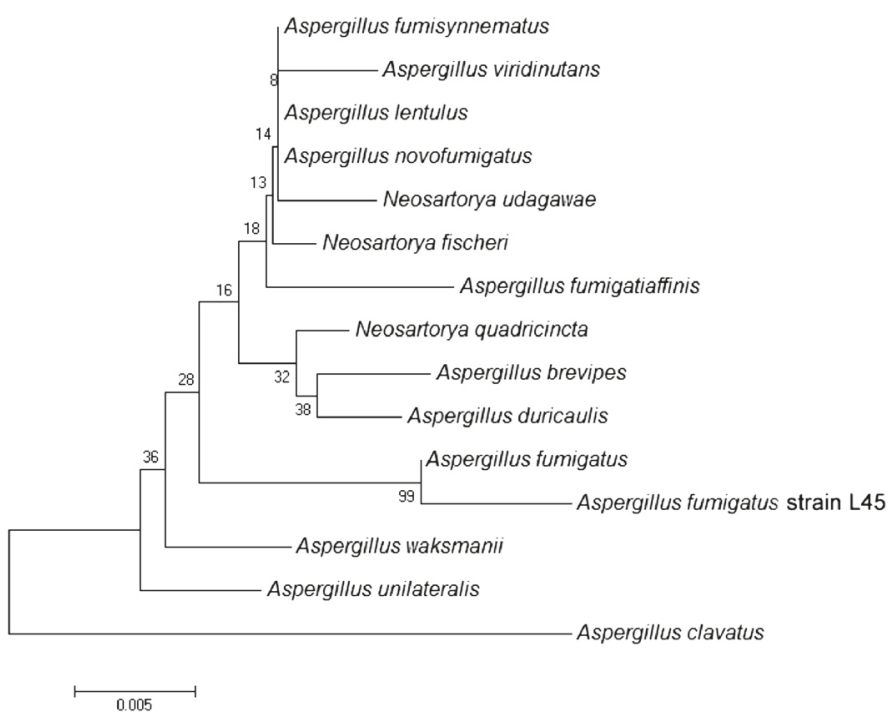

Fig. 4 18S rDNA gene sequence (a) and phylogenetic analysis (b) of Aspergillus fumigatus L45. The numbers above (under) the nodes represent bootstrap values

was in highly agreement with the predicted value of $361.3 \mathrm{U} / \mathrm{mL}$. As a result, the validity of the regression model was satisfactory.

In literature, many studies referred to the optimal fermentation parameters for the production of polygalacturonase. For instance, a polygalacturonase produced from
A. fumigatus Fres. MTCC 4163 showed maximum activity of $1270 \mathrm{U} / \mathrm{g}$ when fermented at $50{ }^{\circ} \mathrm{C}$ and $\mathrm{pH} 4.0-5.0$ for 2-3 days [4]. A polygalacturonase activity was the highest (ca. $2 \mathrm{U} / \mathrm{mL}$ ) when the strain $T$. aurantiacus was cultivated at $45{ }^{\circ} \mathrm{C}$ and $\mathrm{pH} 5.5$ for 5 days in submerged fermentation with pectin as the substrate [1]. Penicillium 
Table 2 RSM design and experimental results

\begin{tabular}{lllll}
\hline No. & $\begin{array}{l}\text { Inoculums } \\
\text { concentration (\%) }\end{array}$ & Temperature $\left({ }^{\circ} \mathrm{C}\right)$ & $\mathrm{pH}$ & $\begin{array}{l}\text { Polygalacturonase } \\
\text { activity }(\mathrm{U} / \mathrm{mL})\end{array}$ \\
\hline 1 & 0.08 & 50 & 5.0 & 278.3 \\
2 & 0.04 & 40 & 5.0 & 286.7 \\
3 & 0.06 & 45 & 5.0 & 364.9 \\
4 & 0.08 & 40 & 5.0 & 305.8 \\
5 & 0.06 & 50 & 4.5 & 250.2 \\
6 & 0.04 & 50 & 5.0 & 253.3 \\
7 & 0.08 & 45 & 5.5 & 297.1 \\
8 & 0.06 & 50 & 5.5 & 264.8 \\
9 & 0.06 & 40 & 4.5 & 240.3 \\
10 & 0.06 & 40 & 5.5 & 234.0 \\
11 & 0.06 & 45 & 5.0 & 360.0 \\
12 & 0.06 & 5.0 & 364.9 \\
13 & 0.06 & 45 & 5.0 & 351.5 \\
14 & 0.08 & 45 & 4.5 & 312.8 \\
15 & 0.04 & 45 & 5.5 & 290.8 \\
16 & 0.04 & 45 & 4.5 & 302.6 \\
17 & 0.06 & 45 & 5.0 & 359.0 \\
\hline
\end{tabular}

SPC-F 20 produced the maximum polygalacturonase activity of ca. $1.8 \mathrm{U} / \mathrm{mL}$ when the fungus was cultivated at $30{ }^{\circ} \mathrm{C}$ and $\mathrm{pH} 5.0$ for 3 days with pectin as the substrate [22]. A. niger DMF 27 produced the maximum polygalacturonase activity $(3.8 \mathrm{U} / \mathrm{mL}$ for endo-polygalacturonase and $11.1 \mathrm{U} / \mathrm{mL}$ for exo-polygalacturonase) when fermented at $30{ }^{\circ} \mathrm{C}$ and $\mathrm{pH} 5.0$ for $72 \mathrm{~h}$ using pectin as the substrate [32]. A. foetidus var. pallidus Ege-K-730 produced the highest polygalacturonase activity of $122 \mathrm{U} / \mathrm{mL}$ when incubated at $\mathrm{pH} 2.3$ for $72 \mathrm{~h}$ [33]. By comparison, these results with ours (maximum activity of $359.1 \mathrm{U} / \mathrm{mL}$ at $45{ }^{\circ} \mathrm{C}$ and $\mathrm{pH} 5$ for $36 \mathrm{~h}$ ), it is obviously seen that the optimal fermentation temperature and $\mathrm{pH}$ in this study were moderate, while the fermentation time was much shorter than that in literature. Besides, since the activity could be greatly affected by different source of substrates, the polygalacturonase activities in literature could just be roughly compared. In summary, A. fumigatus L45 would be a promising fungus to produce thermostable polygalacturonase in the future.

\section{Enzymatic properties of the polygalacturonase}

Polygalacturonase produced by A. fumigatus L45 was purified according to the method described by Fachin et al. [34]. Pooled fractions of polygalacturonase were applied on a gel filtration column (Hi Load 16/60 Superdex 75). The activity and molar mass of purified polygalacturonase were estimated. From Fig. 6, the molecular weight of polygalacturonase was about $45 \mathrm{kDa}$ according to SDS-
Table 3 The main effective analysis of variance (ANOVA) of RSM data

\begin{tabular}{llllll}
\hline Source & Sum of squares & DF & Mean square & $F$ value & $P$ value \\
\hline Model & 31248.93 & 9 & 3472.10 & 14.59 & $0.0009^{* *}$ \\
$X_{1}$ & 459.44 & 1 & 459.44 & 1.93 & 0.2073 \\
$X_{2}$ & 50.73 & 1 & 50.73 & 0.21 & 0.6583 \\
$X_{3}$ & 45.77 & 1 & 45.77 & 0.19 & 0.6742 \\
$X_{1} X_{2}$ & 9.08 & 1 & 9.08 & 0.04 & 0.8507 \\
$X_{1} X_{3}$ & 3.56 & 1 & 3.56 & 0.01 & 0.9062 \\
$X_{2} X_{3}$ & 108.99 & 1 & 108.99 & 0.46 & 0.5203 \\
$X_{1}^{2}$ & 687.33 & 1 & 687.33 & 2.89 & 0.1331 \\
$X_{2}^{2}$ & 18494.31 & 1 & 18494.31 & 77.70 & $<0.0001^{* *}$ \\
$X_{3}^{2}$ & 9095.86 & 1 & 9095.86 & 38.21 & $0.0005^{* *}$ \\
Residual & 1666.17 & 7 & 238.02 & & \\
Lack of fit & 1545.40 & 3 & 515.13 & 17.06 & 0.96 \\
Pure error & 120.77 & 4 & 30.19 & & \\
Total & 32915.09 & 16 & & & \\
$R^{2}$ & 0.9494 & & & & \\
\hline$D F$ degree of freedom, $R^{2}$ the coefficient of determination \\
**means significance
\end{tabular}

PAGE image, which is almost in agreement with the data reported in the literature [34-37] and the activity was $25,500 \mathrm{U} / \mathrm{mg}$ after purification. Furthermore, the enzymatic properties of polygalacturonase, such as $\mathrm{pH}$ effect and stability, temperature effect and thermostability, metal ions effect, and kinetic parameters $\left(K_{\mathrm{m}}\right.$ and $\left.V_{\max }\right)$, were investigated. The results were shown in Fig. 7.

\section{pH effect and $\mathrm{pH}$ stability}

The effect of $\mathrm{pH}$ on polygalacturonase activity and its $\mathrm{pH}$ stability were investigated, and the results were depicted in Fig. 7a. It was observed that the polygalacturonase showed the maximal enzyme activity at $\mathrm{pH}$ 5.0. Beyond that $\mathrm{pH}$ value, the polygalacturonase activity presented a decreasing tendency. This phenomenon was in accordance with those results in literature $[24,10,38] . \mathrm{pH}$ stability of polygalacturonase showed that the residual activity was maintained over $80 \%$ after $24 \mathrm{~h}$ of incubation from $\mathrm{pH} 2.0$ to 7.0. By comparing the $\mathrm{pH}$ stability with other polygalacturonase listed in Table 4, it can be indicated that the polygalacturonase from A. fumigatus $\mathrm{L} 45$ showed high $\mathrm{pH}$ stability within neutral $\mathrm{pH}$ values.

\section{Temperature effect and thermostability}

Experiments were conducted to investigate the effect of temperature on polygalacturonase activity and its thermostability, and the results were shown in Fig. 7b. It was revealed that the optimum temperature for polygalacturonase activity was $60{ }^{\circ} \mathrm{C}$. Even at $80{ }^{\circ} \mathrm{C}$, the polygalacturonase could still keep $63 \%$ catalytic activity. The thermostability 


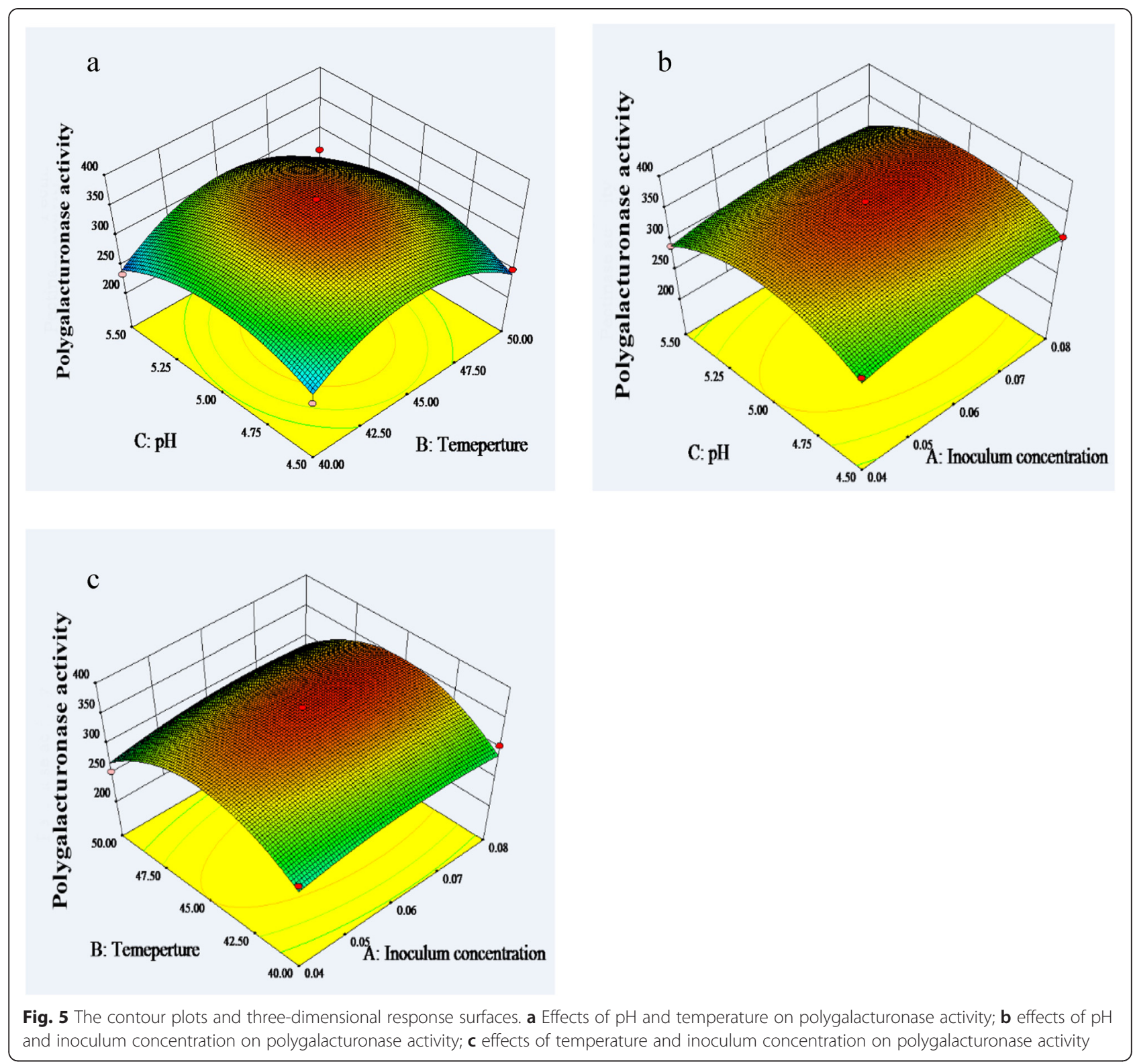

of the polygalacturonase showed that the residual activities of 100,80 , and $54 \%$ were obtained at 50,60 , and $80^{\circ} \mathrm{C}$ for $2 \mathrm{~h}$ incubation, respectively.

In literature, a polygalacturonase from $A$. fumigatus strain 4 showed the highest activity at $65{ }^{\circ} \mathrm{C}$. However, the enzyme was only stable at $4-6{ }^{\circ} \mathrm{C}$. When stored at $26-30{ }^{\circ} \mathrm{C}$, its activity was reduced by $24 \%$ [39]. Another pectinase from $A$. fumigatus showed maximal activity at $40{ }^{\circ} \mathrm{C}$ and pH 5.5 and was stable up to $40{ }^{\circ} \mathrm{C}$ [40]. A polygalacturonase produced by Penicillium strain presented a residual activity of $48 \%$ after $2 \mathrm{~h}$ incubation at $60{ }^{\circ} \mathrm{C}$ [22]. A polygalacturonase producing from $T$. aurantiacus showed a residual activity of $13 \%$ after 1-h incubation at $60{ }^{\circ} \mathrm{C}$ [1]. Other related data were shown in Table 4. Through comparison of characters of polygalacturonase reported in literature, it was confirmed that the polygalacturonase from A. fumigatus L45 showed good thermostability.

\section{Effects of metal ions on enzyme activity}

The effects of different metal ions on the polygalacturonase activity were evaluated, and the results were shown in Fig. 7c. It can be seen that metal ions $\mathrm{Na}^{+}$and $\mathrm{Ca}^{2+}$ showed almost noninfluence on the polygalacturonase activity, $\mathrm{K}^{+}$inhibited the polygalacturonase activity by ca. $25 \%, \mathrm{Mg}^{2+}$ enhanced the polygalacturonase activity by $25 \%$, and $\mathrm{Zn}^{2+}$ could increase the polygalacturonase activity to 1.80 -fold. The activity of a polygalacturonase 

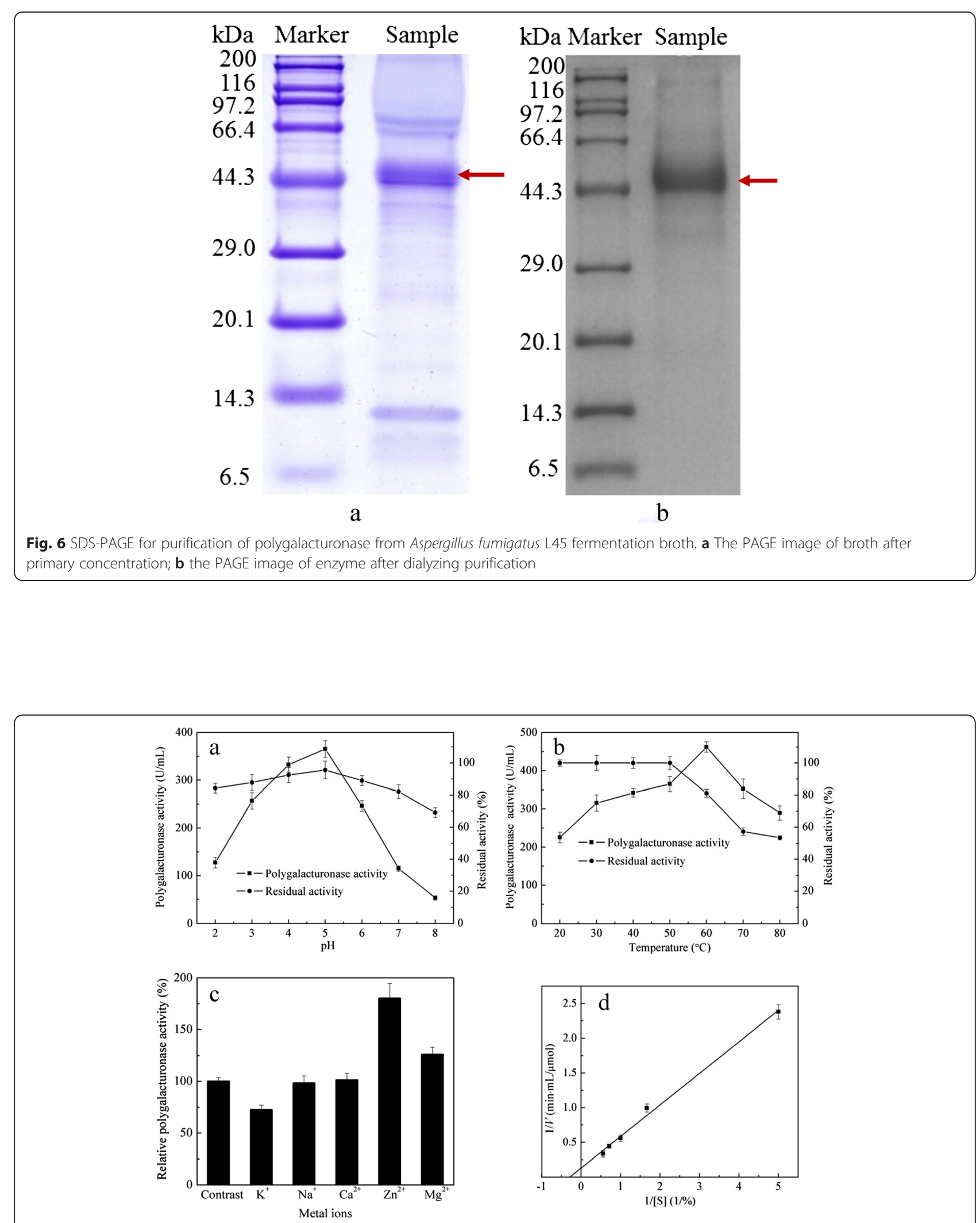

Fig. 7 Characteristics of the polygalacturonase. a Effect of pH on the polygalacturonase activity and pH stability for 24-h incubation; $\mathbf{b}$ effect of temperature on the polygalacturonase activity and thermostability for 2-h incubation; c effects of metal ions on the polygalacturonase activity; d Lineweaver-Burk plot for polygalacturonase activity 
Table 4 Comparisons of enzymology properties of polygalacturonase reported in the literatures

\begin{tabular}{|c|c|c|c|c|c|c|}
\hline No. & Strains & $\begin{array}{l}\text { Optimal } \\
\text { temperature }\left({ }^{\circ} \mathrm{C}\right)\end{array}$ & Optimal pH & $K_{\mathrm{m}}(\mathrm{mg} / \mathrm{mL})$ & Stability & Refs. \\
\hline 1 & Sckrotinia sclerotiorum & 45 & 5.0 & 0.83 & Mostly inactive at $65^{\circ} \mathrm{C}$, & {$[42]$} \\
\hline 2 & Aspergillus fumigatus strain 4 & 65 & $3.5-4.5$ & - & $\begin{array}{l}\text { Stable between } 3.0 \text { and } 9.0 \text { and at } 4-6^{\circ} \mathrm{C} ; \\
\text { activity reduce by } 24 \% \text { at } 26-30{ }^{\circ} \mathrm{C}\end{array}$ & [39] \\
\hline 3 & Aspergillus niger & 43 & $3.8-4.3$ & 0.12 & $T_{m}=43^{\circ} \mathrm{C}$ & [18] \\
\hline 4 & Aspergillus niger & 45 & $3,4.6$ & 0.72 & $T_{m}=46^{\circ} \mathrm{C}$ & [18] \\
\hline 5 & Penicillium viridicatum $\mathrm{Rfc} 3$ & 55 & 5 & - & Stable in neutral $\mathrm{pH}$ range and at $40^{\circ} \mathrm{C}$ for $1 \mathrm{~h}$ & [43] \\
\hline 6 & Thermoascus aurantiacus 179-5 & 65 & 5 & - & $\begin{array}{l}\text { Stable in the acidic to neutral } \mathrm{pH} \text { range } \\
\text { at } 60^{\circ} \mathrm{C} \text { for } 1 \mathrm{~h}\end{array}$ & [44] \\
\hline 7 & Penicillium SPC-F 20 & 60 & 5.5 & - & $\begin{array}{l}\text { A residual activity of } 48 \% \text { after } 2 \mathrm{~h} \text { of } \\
\text { incubation at } 60^{\circ} \mathrm{C}\end{array}$ & [22] \\
\hline 8 & $\begin{array}{l}\text { Rhizopus microsporus var. } \\
\text { rhizopodiformis }\end{array}$ & 65 & 3.5 & & $\begin{array}{l}\text { Activity decreased by } 28 \text { and } 39 \text { at } 60 \text { and } \\
65^{\circ} \mathrm{C} \text {, respectively, for } 90 \text {-min incubation }\end{array}$ & {$[45]$} \\
\hline 9 & Thermoascus aurantiacus & 60 & 5.0 & - & Stable in $\mathrm{pH} 3.0-4.5$ at $55^{\circ} \mathrm{C}$ for $1 \mathrm{~h}$ & [1] \\
\hline 10 & Rhizomucor pusilis & 55 & 5.0 & 0.22 & $\begin{array}{l}\text { Stable up to } 50^{\circ} \mathrm{C} \text { for } 120 \mathrm{~min} \text { at } \mathrm{pH} 4.0-5.0 \text {; } \\
\text { decreased rapidly above } 60^{\circ} \mathrm{C} \text { and above } \mathrm{pH} 5.0\end{array}$ & [8] \\
\hline 11 & Penicillium oxalicum SX6 & 50 & 5.0 & - & Stable at pH $3.5-6.0$ and $40{ }^{\circ} \mathrm{C}$ & [13] \\
\hline 12 & Aspergillus fumigatus & 60 & 5.0 & 35 & Stable at $\mathrm{pH} 2.0-7.0$ and $60^{\circ} \mathrm{C}$ for $2 \mathrm{~h}$ & In our work \\
\hline
\end{tabular}

from $A$. niger was inhibited by $\mathrm{K}^{+}, \mathrm{Zn}^{2+}$, and $\mathrm{Ca}^{2+}$ to $55.83,43.11$, and $73.02 \%$, respectively, while promoted by $\mathrm{Mg}^{2+}$ by 11.55 -fold [8]. The activity of another polygalacturonase from thermophilic fungus $T$. aurantiacus was inhibited 59, 77, and $100 \%$ by $\mathrm{Zn}^{2+}, \mathrm{Mn}^{2+}$, and $\mathrm{Hg}^{2+}$, respectively [24].

\section{Kinetic parameters $\left(K_{m}\right.$ and $\left.V_{\max }\right)$}

The enzyme kinetic parameters $K_{\mathrm{m}}$ and $V_{\max }$ from Michaelis-Menten equation were determined through the Lineweaver-Burk plot (seen in Fig. $7 d$ ). $V_{\max }$ represents the maximum rate the system can achieved at saturating substrate concentrations. $K_{\mathrm{m}}$ is the substrate concentration at which the reaction rate is half of $V_{\text {max }}$; therefore, $K_{\mathrm{m}}$ is negatively related to the affinity of the enzyme to the substrate. The $K_{\mathrm{m}}$ and $V_{\max }$ values of polygalacturonase were $35.0 \pm 2.8 \mathrm{mg} / \mathrm{mL}$ (or $3.5 \pm 0.28 \%$ ) and $7.69 \pm 0.59 \mu \mathrm{mol} / \mathrm{mL} / \mathrm{min}$, respectively, in this work. Further, we obtained the $K_{\text {cat }}$ value of $1.38 \mathrm{~min}-1$ following the equation of $K_{\mathrm{cat}}=V_{\max } /$ enzyme concentration. So $K_{\text {cat }} / K_{\mathrm{m}}$ was $0.04 \mathrm{mg} / \mathrm{mL} / \mathrm{min}$.

Kant et al. [8] demonstrated that the $K_{\mathrm{m}}$ and $V_{\max }$ values of a purified polygalacturonase from $A$. niger MTCC 3323 were $0.083 \mathrm{mg} / \mathrm{mL}$ and $18.21 \mu \mathrm{mol} / \mathrm{mL} / \mathrm{min}$, respectively, using polygalacturonic acid as a substrate. Rashad et al. [41] confirmed that $K_{\mathrm{m}}$ and $V_{\max }$ values of a purified polygalacturonase from Pleurotus ostreatus were $1.33 \mathrm{mg} / \mathrm{mL}$ and $28.6 \mu \mathrm{mol} / \mathrm{mL} / \mathrm{min}$, respectively, using pectin as a substrate. Other $K_{\mathrm{m}}$ values from references were presented in Table 4. The high $K_{\mathrm{m}}$ and lower $V_{\max }$ values of our polygalacturonase mainly stemmed from the fact that the enzyme was just primarily purified and had a relatively low purity.

\section{Conclusions}

A thermophilic polygalacturonase-producing strain $A$. fumigatus L45 was screened from the pile fermentation of Pu'er tea in China. The fermentation parameters of the strain were optimized by RSM, and the result showed that the polygalacturonase achieved a maximum activity of $359.1 \pm 10.1 \mathrm{U} / \mathrm{mL}$ under the optimized conditions (inoculum concentration of $0.07 \%(\mathrm{v} / \mathrm{v})$, temperature of $45{ }^{\circ} \mathrm{C}$, and $\mathrm{pH}$ 5.0). The optimal temperature and $\mathrm{pH}$ for polygalacturonase were $60{ }^{\circ} \mathrm{C}$ and $\mathrm{pH}$ 5.0. The enzyme maintained 100,80 , and $54 \%$ of its activity after incubated at 50 , 60 , and $80{ }^{\circ} \mathrm{C}$ for $2 \mathrm{~h}$, respectively. The good thermostability and $\mathrm{pH}$ stability suggested that the enzyme has potential applications in the biofuel and textile industries. The polygalacturonase gene cloning, protein structural biology, and applications are ongoing in our lab.

\section{Abbreviations \\ ANOVA: analysis of variance; $D_{c}$ : the diameter of the colony; DNA: 3,5-dinitrosalicylic acid; $D_{\mathrm{p}}$ : the diameters of the pectin degradation halos; LB: Luria-Bertani; $R^{2}$ : coefficient of determination; RSM: response surface methodology; SEM: scanning electron microscope; YEPD: yeast extract peptone dextrose; BB design: Box-Behnken design.}

\section{Competing interests}

The authors declare that they have no competing interests.

\section{Authors' contributions}

SW wrote the draft manuscript. ZL performed all the experimental works. LW checked the figures and referecnes formation. XY confirmed the SDS-page experimental data. and $\mathrm{YL}$ designed the experiments and proofread the manuscript. All authors read and approved the final manuscript.

Received: 26 March 2015 Accepted: 30 June 2015

Published online: 21 July 2015 


\section{References}

1. da Silva ME, Leite RSR, da Silva R, Gomes E (2012) Production and characterization of polygalacturonase from thermophilic Thermoascus aurantiacus on submerged fermentation. Ann Microbiol 62(3):1199-1205

2. Malvessi E, Silveira MM (2004) Influence of medium composition and pH on the production of polygalacturonases by Aspergillus oryzae. Braz Arch Biol Technol 47(5):693-702

3. Heerd D, Yegin S, Tari C, Fernandez-Lahore M (2012) Pectinase enzyme-complex production by Aspergillus spp. in solid-state fermentation: a comparative study. Food Bioprod Process 90(2):102-110

4. Phutela U, Dhuna V, Sandhu S, Chadha B (2005) Pectinase and polygalacturonase production by a thermophilic Aspergillus fumigatus isolated from decomposting orange peels. Braz J Microbio 36(1):63-69

5. Kaur A, Mahajan R, Singh A, Garg G, Sharma J (2011) A novel and cost effective methodology for qualitative screening of alkalo-thermophilic cellulase free xylano-pectinolytic microorganisms using agricultural wastes. World J Microb Biotechnol 27(2):459-463

6. Ouattara HG, Koffi BL, Karou GT, Sangare A, Niamke SL, Diopoh JK (2008) Implication of Bacillus $\mathrm{sp}$ in the production of pectinolytic enzymes during cocoa fermentation. World J Microb Biotechnol 24(9):1753-1760

7. Jayani RS, Saxena S, Gupta R (2005) Microbial pectinolytic enzymes: a review. Process Biochem 40(9):2931-2944

8. Kant S, Vohra A, Gupta R (2013) Purification and physicochemical properties of polygalacturonase from Aspergillus niger MTCC 3323. Protein Expres Purif 87(1):11-16

9. Oyeleke S, Oyewole O, Egwim E, Dauda B, Ibeh E (2012) Cellulase and pectinase production potentials of Aspergillus niger isolated from corn cob. Bayero J Pure Appl Sci 5(1):78-83

10. Sandri IG, Lorenzoni CMT, Fontana RC, da Silveira MM (2013) Use of pectinases produced by a new strain of Aspergillus niger for the enzymatic treatment of apple and blueberry juice. LWT-Food Sci Technol 51(2):469-475

11. Lan L, Zhou Q, Cai Q, Dong X, Wang P, Jiang D (2011) Screening and identification of a high-yield pectinase Penicillium strain. J Zhejiang Normal Uni (Natural Sci) 4:452-456

12. Banu AR, Devi MK, Gnanaprabhal G, Pradeep B, Palaniswamy M (2010) Production and characterization of pectinase enzyme from Penicillium chrysogenum. Indian J Sci Techn 3(4):377-381

13. Tu T, Bai YG, Luo HY, Ma R, Wang YR, Shi PJ et al (2014) A novel bifunctional pectinase from Penicillium oxalicum SX6 with separate pectin methylesterase and polygalacturonase catalytic domains. Appl Microbiol Biot 98(11):5019-5028. doi:10.1007/s00253-014-5533-x

14. Qureshi AS, Bhutto MA, Chisti Y, Khushk I, Dahot MU, Bano S (2012) Production of pectinase by Bacillus subtilis EFRL 01 in a date syrup medium. Afr J Biotechnol 11:12563-12570

15. Rehman HU, Aman A, Silipo A, Qader SAU, Molinaro A, Ansari A (2013) Degradation of complex carbohydrate: immobilization of pectinase from Bacillus licheniformis KIBGE-IB21 using calcium alginate as a support. Food Chem 139(1):1081-1086

16. Tepe O, Dursun AY (2014) Exo-pectinase production by Bacillus pumilus using different agricultural wastes and optimizing of medium components using response surface methodology. Environ Sci Pollut R 21(16):9911-9920

17. Kittur FS, Vishu Kumar AB, Tharanathan RN (2003) Low molecular weight chitosans - preparation by depolymerization with Aspergillus niger pectinase, and characterization. Carbohyd Res 338(12):1283-1290

18. Singh SA, Appu Rao A (2002) A simple fractionation protocol for, and a comprehensive study of the molecular properties of, two major endopolygalacturonases from Aspergillus niger. Biotechnol Appl Biochem 35(2):115-123

19. Corredig M, Kerr W, Wicker L (2000) Separation of thermostable pectinmethylesterase from marsh grapefruit pulp. J Agr Food Chem 48(10):4918-4923

20. Mei Y, Chen Y, Zhai R, Liu Y (2013) Cloning, purification and biochemical properties of a thermostable pectinase from Bacillus halodurans M29. J Mol Catal B Enzym 94(0):77-81. doi:10.1016/ j.molcatb.2013.05.004

21. Pakarinen A, Zhang J, Brock T, Maijala P, Viikari L (2012) Enzymatic accessibility of fiber hemp is enhanced by enzymatic or chemical removal of pectin. Bioresource Technol 107:275-281
22. Mathew A, Eldo AN, Molly A (2008) Optimization of culture conditions for the production of thermostable polygalacturonase by Penicillium SPC-F 20. J Ind Microbiol Biotechnol 35(9):1001-1005

23. Maller A, Damásio ARL, Silva TMd, Jorge JA, Terenzi HF, Polizeli MdLTdM (2011) Biotechnological potential of agro-industrial wastes as a carbon source to thermostable polygalacturonase production in Aspergillus niveus. Enzyme research. 2011:6. Article ID 289206, doi: 289210.284061/282011/289206

24. Martins ES, Leite RSR, da Silva R, Gomes E (2013) Purification and properties of polygalacturonase produced by thermophilic fungus Thermoascus aurantiacus CBMAl-756 on solid-state fermentation. Enzyme research 438645:1. doi:438610.431155/432013/438645

25. Zeni J, Cence K, Grando CE, Tiggermann L, Colet R, Lerin LA et al (2011) Screening of pectinase-producing microorganisms with polygalacturonase activity. Appl Biochem Biotechnol 163(3):383-392. doi:10.1007/s12010-0109046-5

26. Lin Q, Liu Y (2010) A new marine microorganism strain L0804: taxonomy and characterization of active compounds from its metabolite. World J Microb Biotechnol 26(9):1549-1556

27. Dong S, Huang Y, Zhang R, Lian Z, Wang S, Liu Y (2014) Inclusion complexes of astaxanthin with hydroxypropyl- $\beta$-cyclodextrin: parameters optimization, spectroscopic profiles, and properties. Eur J Lipid Sci Technol 116(8):978-986

28. Liu Y, Yan Y, Hu F, An Y, Wang Z, Wei F (2010) Transesterification for biodiesel production catalyzed by combined lipases: optimization and kinetics. Aiche J 56(6):1659-1665

29. Wang S, Sun Z, Dong S, Liu Y, Liu Y (2014) Molecular interactions between (-)-epigallocatechin gallate analogs and pancreatic lipase. PLoS ONE 9(11), e111143. doi:10.1371/journal.pone.0111143

30. Ghani M, Ansari A, Aman A, Zohra RR, Siddiqui NN, Qader SAU (2013) Isolation and characterization of different strains of Bacillus licheniformis for the production of commercially significant enzymes. Pak J Pharm Sci 26(4):691-697

31. Babavalian H, Amoozegar MA, Pourbabaee AA, Moghaddam MM, Shakeri F (2013) Isolation and identification of moderately halophilic bacteria producing hydrolytic enzymes from the largest hypersaline playa in Iran. Microbiology 82(4):466-474

32. Patil SR, Dayanand A (2006) Optimization of process for the production of fungal pectinases from deseeded sunflower head in submerged and solid-state conditions. Bioresour Technol 97(18):2340-2344. doi:10.1016/j.biortech.2005.10.025

33. Taşkin E, Eltem R, Silva ES, Souza JVB (2008) Screening of Aspergillus strains isolated from vineyards for pectinase production. Journal of food, agriculture \& environment 6:412-414

34. Fachin D, Smout C, Verlent I, Ly Nguyen B, Van Loey A, Hendrichx M (2004) Inactivation kinetics of purified tomato polygalacturonase by thermal and high-pressure processing. J Agric Food Chem 52:2697-2703

35. Tucker GA, Robertsons NG, Grierson D (1981) The conversion of tomato-fruit polygalacturonase isoenzyme 2 into isoenzyme 1 in vitro. Eur J Biochem 115:87-90

36. Ali ZM, Brady CJ (1982) Purification and characterization of the polygalacturonases of tomato fruits. Aust J Plant Physiol 9:155-169

37. Moshrefi M, Luh BS (1984) Purification and characterization of two tomato polygalacturonase isoenzymes. J Food Biochem 8:39-54

38. Siddiqui MA, Pande V, Arif M (2012) Production, purification, and characterization of polygalacturonase from Rhizomucor pusillus isolated from decomposting orange peels. Enzyme Res. 2012:8. Article ID 138634, doi:138610.131155/132012/138634

39. Baracat-Pereira MC, Vanetti MCD, de Araujo EF, Silva DO (1993) Partial characterization of Aspergillus fumigatus polygalacturonases for the degumming of natural fibers. J Ind Microbiol 11(3):139-142

40. Ezugwu A, Eze S, Chilaka F, Anyanwu C (2013) Production and characterization of pectinases obtained from Aspergillus fumigatus in submerged fermentation system using pectin extracted from mango peels as carbon source. Plant Products Research Journal 16(1):47-53

41. Rashad MM, Abdou HM, Shousha WG, Ali MM, El-Sayed NN (2010) Purification and characterization of extracellular polygalacturonase from Pleurotus Ostreatus using citrus limonium waste. J Appl Sci Res 6(1):81-88

42. Riou C, Freyssinet G, Fevre M (1992) Purification and characterization of extracellular pectinolytic enzymes produced by Sclerotinia sclerotiorum. Appl Environ Microbiol 58(2):578-583

43. Silva D, Martins ES, Rd S, Gomes E (2002) Pectinase production by Penicillium viridicatum RFC3 by solid state fermentation using agricultural wastes and agro-industrial by-products. Braz J Microbio 33:318-324 
44. Martins E, Silva D, Da Silva R, Gomes E (2002) Solid state production of thermostable pectinases from thermophilic Thermoascus aurantiacus. Process Biochem 37(9):949-954

45. Damásio ARL, Maller A, Silva TM, Jorge JA, Terenzi HF, Polizeli MLT (2011) Biotechnological potential of alternative carbon sources for production of pectinases by Rhizopus microsporus var. rhizopodiformis. Braz Arch Biol Technol 54(1):141-148

Submit your manuscript to a SpringerOpen ${ }^{\odot}$ journal and benefit from:

- Convenient online submission

- Rigorous peer review

- Immediate publication on acceptance

- Open access: articles freely available online

- High visibility within the field

- Retaining the copyright to your article

Submit your next manuscript at $\gg$ springeropen.com 